\title{
PROFILE: DARRAGH MORGAN
}

Darragh Morgan is the violinist and founding member of the Fidelio Trio and has appeared as chamber musician and soloist at major concert venues and festivals across the world. The Fidelio Trio are currently Artists in Residence at St Patrick's College, Dublin. Previously, as violinist with The Smith Quartet, Darragh performed and recorded with artists such as Philip Glass, Louis Andriessen, Gavin Bryars and Steve Reich, and made an acclaimed recording

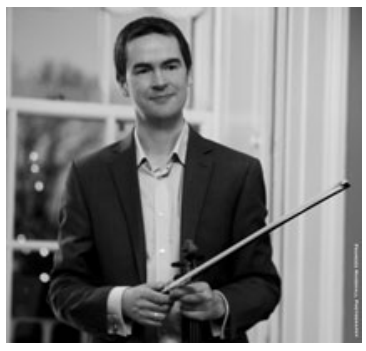

Darragh Morgan photo by Frances Marshall of Philip Glass's complete string quartets on Signum Records. Darragh has also many ensembles, including Ensemble Modern, the London Sinfonietta, Musik Fabrik, Birmingham Contemporary Music Group, Remix Ensemble, Athelas Sinfonietta and Red Note Ensemble.

Darragh studied with Detlef Hahn at the Guildhall School of Music and Drama, London, and received chamber music coaching from the Amadeus and Takacs Quartets, as well as participating in masterclasses with Sidney Griller, Yehudi Menuhin, Mauricio Fuks, Paul Zukofsky, Pinchas Zukerman, Yfrah Neaman and Pierre Amoyal, and, in the field of Irish traditional music, with the legendary Sligo fiddle player Joe O Dowd. He plays a fine nineteenth-century Italian violin made by Domenico Corbucci and an Irish violin made by Thomas Perry in 1768 .

Darragh has made regular solo appearances with the Ulster Orchestra, including the world premiere of Sir John Tavener's Hymn of Dawn. He has recorded Donnacha Dennehy's Elastic Harmonic with the National Symphony Orchestra of Ireland, with whom he has also premiered Brian Irvine's A Mon Seul Desir; with the Crash Ensemble he gave the world premiere of Andrew Poppy's Darwin's Sin Draw. Darragh has recorded over $50 \mathrm{CDs}$, the most recent being the Saint-Saens and Ravel piano trios for Rosunus Classics.

Q: You are active as a soloist, and as a member of the Fidelio Trio, but is there a role that you prefer?

A: No, I consider myself equally at home as both soloist and chamber musician. I've been very lucky to experience so many different inspiring performing roles. As a guest leader of London Sinfonietta, BCMG, Musik Fabrik and Ensemble Modern I have had the privilege of working closely with amazing conductors including Pierre Boulez, Heinz Holliger and Oliver Knussen. With Ensemble Modern I remember Henze discussing his music with me and a few select colleagues before his seventy-fifth birthday concert, Sciarrino working with me on his Sei Capricci at Festival d'Automne Paris before we performed his opera Macbeth, backstage with Lachenmann talking about his love of Strauss's Alpine Symphony, and recording George Benjamin Palimpsests with the composer conducting. With Remix Ensemble I 
remember wonderful premieres with Emmanuel Nunes and with Musik Fabrik a cool premiere of the three Bang on a Can composers. I've also performed world premieres as soloist with orchestra by John Tavener and Arvo Part which were definitely very special moments in my own performance memory.

With the Fidelio Trio and Smith Quartet, I've enjoyed equally special chamber music collaborations: recording Philip Glass's complete quartets and Michael Nyman's piano trios; relaxed conversations with Steve Reich before Different Trains performances; inspiring, often intense rehearsals before chamber music and solo premieres with Michael Finnissy, Joe Cutler, Chris Newman, Gerald Barry, Howard Skempton, Donnacha Dennehy, Judith Weir and Charles Wuorinen.

Q: What took you into new music?

A: There used to be a competition in Ireland called RTE Musician of the Future (like BBC Young Musician). You were required to play a contemporary piece in the final and even though I didn't win the overall competition they created a prize for me for the 'best performance of a piece of new music'. This was a work called Epilogue, originally for flute and piano, by Raymond Deane. He was a family friend and agreed to adapt it for me for the violin. I think I was 19 then.

Soon after I got involved with Guildhall New Music Ensemble, conducting premieres by Colin Riley and Morgan Hayes during my first year (with Robert Saxton performing the viola part!). By the second year of Guildhall I had got to know Joseph Phibbs who that summer wrote a violin and piano work for me and the following year I participated in the Britten-Pears Contemporary Composition and Performance Course. Fellow musicians included composers such as Richard Causton, who went on to write his Seven States of Rain for Mary Dullea and me, which we recorded on our NMC debut disc Opera, before it was awarded the first ever British Composer Award. I knew by my final recital at Guildhall that new music was going to play a pivotal role in my musical life when I included Elliot Carter's Riconoscenza per Goffredo Petrassi as central to the programme.

Q: With the Fidelio Trio you have one of the great standard repertoire lineups. Is this a problem, or an advantage? How do you feel about the relative virtues of mixed programming or all contemporary programmes?

A: The piano trio, unlike its cousin the string quartet, has, to a certain extent, only recently been dragged kicking into the twenty-first century. Works such as Black Angels by George Crumb, Steve Reich's Different Trains or Lachenmann's quartets have helped the string quartet evolve organically with contemporary trends, whereas the classical reputation of the piano trio medium has intimidated a lot of composers until recently. I feel very grateful not only that so many works are written for us but that each creation is for this new, contemporary animal, violin, cello and piano living inside each other, rather than the piano trio of Schumann and Brahms for whom the instruments were much more distinctively separate voices.

I have been playing the Ravel piano trio for over 20 years, giving hundreds of performances of it, often next to brand new repertoire but equally often next to standard, core, classical repertoire. It's a work that perfectly bridges these two worlds, and for us the processes of playing classical repertoire and working with living composers, premiering new works, influence each other tremendously. I couldn't 
live without either. I can't phone Beethoven to ask about unusual articulations and tempo markings, but I do feel a direct link to the creative spirit by the opportunity for dialogue and being tested by living composers.

One of the difficulties of an all-contemporary programme is that often it isn't entirely chosen by the performer. With festivals, commissions, broadcasts, premieres are on someone else's agenda, which does make choosing an entirely balanced contemporary programme for piano trio challenging. That said, given the opportunity to present a programme entirely of new music always excites me because there is so much brilliant repertoire out there that that we still have to discover and champion.

Q: Do you think there's anything intrinsically different about playing new music? Do you need a different technique, a different expressivity?

A: Yes and no. You certainly need an instrumental facility, and lots of it, to get around much of the challenging writing in contemporary music. But as I mentioned earlier, having played classical repertoire since I was seven years of age, this approach to style (and expressivity) has a direct influence on how I approach playing new music. For example, in 1999 I took a year out to study period performance as a member of the European Union Baroque Orchestra. The influences of working closely with Roy Goodman, Lars Ulrik Mortensen and later, John Eliot Gardiner, and learning to use a Baroque bow naturally, has had a direct impact on how I approach Morton Feldman and John Cage, for example. From a young age I played Irish traditional music and this experience has had another knock-on effect in my approach to new music, such as the folk idioms of Michael Finnissy's music. My interpretative approach when I recorded his complete violin and piano repertoire came directly from my many years of folk music playing.

In playing contemporary chamber music, which is my main work, I approach every piece individually. Of course all music is expressive, even if the composer disagrees! However, expressive doesn't have to mean dolce cantabile, vibrato in the nineteenth-century manner. I remember an observation from Christopher Fox many years ago in York after I played Xenakis's enthralling Mikka S. He commented that he didn't realise that Xenakis could sound so beautiful. Is this expressivity or just an individual's approach? 